\title{
Interspecific differences in the effect of fish on marine microbial plankton
}

\author{
Villéger Sébastien ${ }^{1,}{ }^{*}$, Fouilland Eric ${ }^{1}$, Argenty Jérémy ${ }^{1}$, Bouvier Corinne ${ }^{1}$, Carre Claire ${ }^{1}$, Bouvier \\ Thierry ${ }^{1}$
}

1 Univ Montpellier, CNRS, MARBEC, Ifremer,IRD, F-34095 Montpellier, France.

*Corresponding author : Sébastien Villéger, email address : sebastien.villeger@cnrs.fr

\begin{abstract}
:
The productivity of most marine ecosystems is limited by the availability of dissolved nitrogen ( $\mathrm{N}$ ) and phosphorus $(P)$. Nutrient recycling is therefore a key process for ecosystem functioning. Fish recycle nutrients through the excretion of ammonia and phosphate and can influence the abundance and community structure of primary producers such as phytoplankton. However, the effect of fish on other plankton compartments, and whether all fish species have similar effects, is largely unknown. We used a tank experiment to test how 2 Mediterranean fish species, gilthead seabream Sparus aurata and golden mullet Chelon auratus, with distinctly different $\mathrm{N}$ and $\mathrm{P}$ excretion rates, can affect the abundance and community structure of 3 plankton compartments: phytoplankton, bacterioplankton, and microzooplankton. We found that the nutrients released by seabream (whose excreta had an N:P molar ratio greater than the Redfield ratio of 16:1) induced a substantial increase in the abundance of all plankton compartments. In addition, with seabream, the relative abundance of diatoms in the phytoplankton communities increased. However, no significant change was observed with mullet, which had a low excreta N:P molar ratio, suggesting that the growth of microbial plankton was limited by the availability of $\mathrm{N}$. Our results demonstrate that nutrient excretion by fish affects the microbial food web through a speciesspecific bottom-up effect on the total abundance and community structure of the phytoplankton, bacterioplankton, and microzooplankton communities.
\end{abstract}

Keywords : Marine fish, Nutrient excretion, Protozooplankton, Phytoplankton, Bacteria 


\section{Introduction}

The majority of services provided by marine ecosystems to humans are sustained by the productivity of microbial plankton (Frederiksen et al. 2006, Christensen et al. 2015). In most marine ecosystems, the growth of microbial plankton is limited by the availability of dissolved nitrogen $(\mathrm{N})$ and/or phosphorus (P) (Elser et al. 2007). Nutrient cycling is therefore a key process for the productivity of the whole marine trophic network. Nutrient cycles involve the consumption of dissolved compounds and particulates by microorganisms and macro-organisms, followed by the release of these nutrients through via active or passive routes or by decomposition of the organism (Benitez-Nelson 2000, Voss et al. 2013).

Microbial plankton has been considered for several decades to be dominant in nutrient cycling for aquatic ecosystems (Azam \& Malfatti 2007). Over the past two decades, however, an increasing number of studies have reported that consumer-driven nutrient recycling also plays a major role. This can be driven by either zooplankton, (e.g. Elser \& Urabe 1999) or large vertebrates, such as fish and cetaceans, (Roman \& McCarthy 2010, Layman et al. 2011, Burkepile et al. 2013, Allgeier et al. 2017). Vertebrates ingest the organic matter in their prey, and, after digestion, excrete some of this matter as inorganic or organic nutrients in feces and some as metabolic waste, including dissolved ammonium and phosphate, through the gills and kidneys (Ip \& Chew 2010). Fish are, therefore, involved in recycling nutrients from solid organic forms to dissolved inorganic forms (Vanni 2002, Allgeier et al. 2017). Fish migrate, both within the vertical strata of ecosystems as well as between habitats, and can aggregate into dense shoals which may result in creating biogeochemical hotspots that have a local effect on the ambient nutrient concentrations and, therefore, the biomass and production of organisms whose growth is limited by N and/or P (Meyer \& Schultz 1985, McIntyre et al. 2008, Boulêtreau et al. 2011, Capps \& Flecker 2013, Shantz et al. 2015). For instance, nutrient excretion by an abundant fish species has been shown to increase the total 
phytoplankton biovolume in temperate eutrophic lakes (Schaus \& Vanni 2000). This overall increase in phytoplankton was associated with a shift in phytoplankton community structure because some clades (e.g. Cryptomonads, Euglenophytes) were better able to benefit from the nutrients released by the fish. Most studies on the effects of release of nutrients from fish digestion and metabolism have been in freshwater ecosystems (Schaus \& Vanni 2000, Vanni et al. 2002, McIntyre et al. 2008). In marine ecosystems, fish can reach high total biomass (>100 g/m $\mathrm{m}^{3}$ in coastal ecosystems) potentially having a major effect on nutrient recycling (Allgeier et al. 2017). The few studies carried out on marine fish have focused on the effect of excretion on juvenile coral density, coral growth, and macroalgal cover on coral reefs (Burkepile et al. 2013, Shantz et al. 2015). These studies confirmed that marine fishes can interact with other marine organisms through nutrient supply. However, there is still little information about how fish can affect phytoplankton and bacterioplankton, which are a major part of marine biomass and, therefore, critical for ecosystem functioning. The total abundance of these microorganisms is driven by nutrient availability (bottom-up control), as well as by viral lysis and predation by microzooplankton (top-down control) (Legendre \& Rassoulzadegan 1995, Kirchman 2008). Although they compete with phytoplankton for nitrogen and phosphorus (Danger et al. 2007), bacterioplankton also benefit from the organic carbon released by phytoplankton (Kirchman 2008). Nutrient excretion by fish may increase the abundance of phytoplankton and bacterioplankton directly, and may increase microzooplankton abundance indirectly through trophic interactions.

In addition, $\mathrm{N}$ and $\mathrm{P}$ excretion rates differ between fish species by an order of magnitude (Allgeier et al. 2015, Vanni \& McIntyre 2016). These differences are driven by differences in body mass (allometric scaling of metabolic rate), body nutrient content and diet nutrient content all of which affect the nutrient budget. The nutrients required for growth and 
elemental homeostasis are also different for autotrophic and heterotrophic microorganisms and even for microorganisms with same energy pathways (e.g. Tilman 1986, Litchman et al. 2004, Danger et al 2008, Hibbing et al. 2010). Therefore, the amounts of $\mathrm{N}$ and P released by fish, as well as the $\mathrm{N}: \mathrm{P}$ ratio, could have different effects on different taxa within the plankton, depending on their abilities to take up, incorporate, store and release elements (Frost et al. 2005, Danger et al 2008, Marañón et al. 2013, Donald et al. 2013). It is, therefore, likely that fish species with different nutrient excretion rates will have different effects on the abundance of different plankton taxa.

In this study, we assessed the effects of nutrient excretion by fish on marine planktonic communities using a tank experiment. Our main objective was to assess how two fish species (gilthead seabream Sparus aurata and golden grey mullet Chelon auratus), which have different $\mathrm{N}$ and $\mathrm{P}$ excretion rates, change the total abundance and community structure of the phytoplankton, bacterioplankton and microzooplankton.

\section{Materials and methods}

\section{The experiment}

To test for differences in the effect of different fish on microbial plankton we selected two fish species with a high abundance of juveniles in coastal Mediterranean lagoons and with different ecologies: the gilthead seabream (Sparus aurata) which feeds on invertebrates and the golden grey mullet (Chelon auratus) which feeds mostly on detritus (Froese \& Pauly 2018). A previous study showed that the juveniles of these two species have different nutrient excretion characteristics (Villéger et al. 2012) with higher N excretion rates for S. aurata and higher P excretion rates for L. aurata. We considered three treatments: the "control" treatment 
without fish, the "seabream" treatment with $S$. aurata juveniles and the "mullet" treatment with L. aurata juveniles. The fish biomass, for both treatments with fish, was set to $300 \mathrm{~g} / \mathrm{m}^{3}$ to be close to that observed in the Thau lagoon in early summer (Villéger, pers. obs.).

Juveniles of these two species were caught using a beach seine in Thau lagoon at Bouzigues, France, $43^{\circ} 26^{\prime} 51^{\prime \prime} \mathrm{N}, 3^{\circ} 39^{\prime} 6^{\prime \prime} \mathrm{E}$, on June 17,2013 . They were then carried back within 3 hours to the laboratory at the University of Montpellier in an aerated plastic container. They were acclimated to the room in 60L tanks filled with seawater from Thau lagoon for 12 days before starting the experiment. The fish were fed twice a day with aquaculture pellets (fish-based pellets for seabream and plant-based pellets for mullet). The last meal was provided $36 \mathrm{~h}$ before starting the experiment to prevent the release of feces in the experimental tanks.

The room with the experiment was maintained at a constant temperature of $18^{\circ} \mathrm{C}$, which is close to the mean daily temperature of the water in the lagoon. We set up 16 tanks with a total volume of $37.5 \mathrm{~L}(50 \times 25 \times 30 \mathrm{~cm}$, length $\times$ width $\times$ depth $)$ with four tanks for the control treatment and six tanks for each treatment with fish. The tanks were arranged on four metal shelves with each shelf having at least one tank of each treatment and with the positions of the four tanks on each shelf selected at random. There was no natural light and each shelf was uniformly lit by cool white fluorescent tubes ( 54 Watt, color temperature $10,000^{\circ} \mathrm{K}$ ) with a day:night cycle of 14:10 h. The tanks were covered with transparent cling film to prevent water evaporation and fish jumping out of the tanks. The sides of tanks were covered with cardboard so that the tanks were lit only from the top.

The day before the start of the experiment, we collected Thau lagoon water from the site where the fish had been caught. The water was immediately filtered through a $64 \mu \mathrm{m}$ nylon 
mesh to remove large zooplankton (e.g. copepods) and taken back to the laboratory in $50 \mathrm{~L}$ plastic containers within 3 hours. Each tank was filled with $25 \mathrm{~L}$ water $(20 \mathrm{~cm}$ deep). The water was oxygenated by an air pump blowing through a clean air stone and water was mixed by a $250 \mathrm{~L} / \mathrm{h}$ electric recirculation pump without a filter. Two sections of clean PVC pipe (diameter $50 \mathrm{~mm}$, length $60 \mathrm{~mm}$ ) were put in each tank to provide shelter for the fish.

After acclimation, the live weight of the fish was $2 \pm 0.5 \mathrm{~g}$ (mean \pm SD) for the two species taken together. We put four seabream $(8.1 \pm 0.6 \mathrm{~g}$, mean $\pm \mathrm{SD})$ or four mullet $(7.8 \pm 0.5 \mathrm{~g})$ into each tank to achieve the target biomass of $300 \mathrm{~g} / \mathrm{m}^{3}$ (7.5 $\mathrm{g}$ in $\left.25 \mathrm{~L}\right)$. The experiment ran for 6 days after introducing the fish. This period was selected as a trade-off between the expected reduction in nutrient excretion rates during fasting and the dynamics of the microbial communities.

\section{Quantifying dissolved nutrient excretion rates}

Just before introducing the groups of four fish into the tanks, we measured the excretion rates for ammonium $\left(\mathrm{NH}_{4}{ }^{+}\right)$and soluble reactive phosphorus (SRP) were measured using the incubation method described by Vanni et al. (2002). Seawater was filtered through a $0.2 \mu \mathrm{m}$ glass-fiber filter and four $50 \mathrm{~mL}$ samples were taken and frozen at $-18^{\circ} \mathrm{C}$ for measuring the nutrient concentrations before incubation. The groups of four fish were placed gently into each of twelve $1.5 \mathrm{~L}$ bags filled with the filtered seawater. Two other bags without fish were filled with the filtered seawater as controls to check for contamination during the incubation. The bags were put in a black plastic box to prevent bias due to stress (Whiles et al. 2009). After one hour the fish were removed from the bags, anesthetized using a clove-oil solution and weighed to the nearest $0.1 \mathrm{~g}$. $50 \mathrm{~mL}$ of water was sampled from each bag and filtered through a $0.2 \mu \mathrm{m}$ glass-fiber filter before being frozen at $-18^{\circ} \mathrm{C}$. $\mathrm{The}^{\mathrm{NHH}}{ }_{4}{ }^{+}$and SRP 
concentrations were assayed using phenol-hypochlorite and molybdenum blue, respectively (Torres \& Vanni 2007).

Mass-specific excretion rates (MSER, $\mu \mathrm{g} \cdot \mathrm{g}^{-1} \cdot \mathrm{h}^{-1}$ ) were calculated for $\mathrm{NH}_{4}{ }^{+}$and SRP, for each group of 4 individuals.

$$
M S E R=\frac{1000 \times V \times\left([I]_{\mathrm{fish}}-[I]_{\mathrm{control}}\right)}{W \times T}
$$

where $V$ is the volume $(\mathrm{L})$ of the water in the plastic bag, $[\mathrm{I}]_{\text {fish }}$ the final concentration $\left(\mathrm{mg} . \mathrm{L}^{-1}\right)$ of ion $I$ in the water with the fish, $[\mathrm{I}]_{\text {control }}$ the final concentration $\left(\mathrm{mg} . \mathrm{L}^{-1}\right)$ of ion $I$ in the controls, W weight ( $\mathrm{g}$ ) of fish in the bag, and $T$ the time (hours) the experiment lasted.

\section{Sampling the microplankton communities}

The microplankton communities in the tanks were sampled just before introducing the fish into the tanks, and just after having removed fish at the end of the experiment. $500 \mathrm{~mL}$ water samples were taken from each tank using a clean, graduated glass beaker. $200 \mathrm{~mL}$ subsamples were taken in acid-washed $(1 \% \mathrm{HCl}$ for $10 \mathrm{~h})$ polycarbonate Nalgene bottles, fixed with formaldehyde (final concentration $2 \%$ ), and stored at $4{ }^{\circ} \mathrm{C}$ for phytoplankton and microzooplankton analysis. $100 \mathrm{~mL}$ subsamples were filtered onto a $47 \mathrm{~mm}$ diameter, $0.2 \mu \mathrm{m}$ pore size polycarbonate filter (Whatman) for bacterioplankton diversity analysis. The filter was put into a $2 \mathrm{~mL}$ Eppendorf tube and immediately frozen at $-80^{\circ} \mathrm{C}$. Finally, a $1 \mathrm{~mL}$ subsample was fixed with formaldehyde (final concentration $2 \%$ ) for $15 \mathrm{~min}$ and stored at $80^{\circ} \mathrm{C}$ for bacterioplankton abundance analysis.

\section{Assessing bacterioplankton abundance and diversity}

The bacterioplankton abundance was determined by flow cytometry. $0.5 \mathrm{ml}$ subsamples were incubated with $0.5 \mu$ l of SYBR ${ }^{\circledR}$ Green I (Molecular Probes Inc) for $15 \mathrm{~min}$ at room 
temperature in the dark. The bacterioplankton were enumerated using a FACSCalibur flow cytometer (Becton Dickinson) with a $15 \mathrm{~mW}, 488 \mathrm{~nm}$, air-cooled argon laser and a standard filter set-up. True count beads (Becton Dickinson) were added to each sample as a standard (Marie et al. 1999).

Bacterial diversity was assessed using Denaturing Gradient Gel Electrophoresis (DGGE) (Muyzer et al. 1993). The bacterial DNA was extracted from the filters using the PowerSoil@ DNA Isolation Kit (Mobio), checked on 1.5\% (w/v) agarose gel using SYBR Green I (Molecular Probes Inc) and quantified using a NanoDrop ND 1000 (Thermoscientific). The V3 region of bacterial 16S rRNA gene (178 bp) was amplified by touchdown PCR (Muyzer et al. 1993) using 10 ng of the extracted DNA with 338f-GC (Øvreås et al. 1997) and 518r (Muyzer et al. 1993) primers and PuRe Taq ${ }^{\circledR}$ Ready-To-Go ${ }^{\circledR}$ PCR beads (GE Healthcare) and a Mastercycler ${ }^{\circledR}$ ep (Eppendorf). The PCR products were checked on $1.5 \%$ (w/v) agarose gel using SYBR Green I (Molecular Probes Inc) and quantified using a NanoDrop ND 1000 (Thermoscientific). The PCR samples were then loaded onto 8\% $(\mathrm{w} / \mathrm{v})$ polyacrylamide gels with a denaturing gradient ranging from 35 to $65 \%$ (100\% corresponding to $7 \mathrm{M}$ urea and $40 \%$ formamide). We loaded $8 \mu \mathrm{l}$ of $100 \mathrm{bp}$ DNA ladder from the same tube of Ready to use ${ }^{\circledR}$ (Euromedex) on each DGGE gel to allow comparing DGGE profiles from all gels. The DGGE was run using an INGENYPhorU (Ingeny) with $0.5 \mathrm{x}$ TAE buffer (Euromedex) at $60^{\circ} \mathrm{C}$ with a constant voltage of $80 \mathrm{~V}$ for $18 \mathrm{~h}$. The DNA was then stained with SYBR ${ }^{\circledR}$ Green (Molecular Probes Inc), and the bands captured using a UV transilluminator with GelDoc ${ }^{\circledR}$ XR (Bio-Rad) and analyzed using Quantity One software (Bio- Rad). Bands were matched with $1 \%$ position tolerance and $1 \%$ optimization. Bands were considered to be indicators of the operational taxonomic units (OTU) present in the sample. The relative intensity of each band was expressed as a fraction 
of the total intensity of all the bands in each sample, and used as estimate of OTU relative abundance.

\section{Quantifying the abundance and community structure of the phytoplankton and} microzooplankton

The phytoplankton cells were identified to the lowest feasible taxonomic level (class, genus or species) using standard references (Tomas et al. 1997, Hoppenrath et al. 2009, Kraberg et al. 2010, Appeltans et al. 2013, Vilicic 2014). The abundances were determined using the Utermöhl method (Utermöhl, 1958; EN 15204:2006). An Axio Imager.A2 microscope at 400x magnification (Zeiss, Oberkochen, Germany) was used with an XCD-U100CR camera (Sony, Minato-ku, Tokyo, Japon) for identification and enumeration. The phytoplankton were clustered in 8 taxonomic groups (Cyanophyceae Prasinophyceae, Chlorophyta excluding Prasinophyceae, Dinophyceae, Bacillariophyceae, Chrysophyceae, Prymnesiophyceae, and Euglenida). We classified microzooplankton as either ciliates or flagellates.

\section{Statistical analyses}

We tested the differences between the three treatments in terms of richness of OTUs and the total abundance of phytoplankton, bacterioplankton and microzooplankton using the nonparametric Kruskal-Wallis test. Where there was a significant effect (p-value $<0.05)$, we tested the differences between pairs of treatments using the non-parametric Dunn post-hoc test with Benjamini-Hochberg correction (Benjamini \& Hochberg 1995). The differences between the community structure of the bacterioplantkon and phytoplankton communities in the three treatments were assessed using the Bray-Curtis distance calculated using the relative abundances of the OTUs or phytoplankton taxonomic groups. The effect of the three 
treatments on the structure of these communities was tested by PERMANOVA applied to the Bray-Curtis distance matrices (Anderson 2001), checking the homogeneity of variance (Anderson 2006). The differences between the community structures were visualized using principal coordinates analysis (PCoA) of the Bray-Curtis distances.

\section{Results}

At the start of the experiment, there were no significant differences between the treatments in the abundance or community structure of the phytoplankton, bacterioplankton, and microzooplankton ( $p$-value $>0.05)$.

\section{Nutrient excretion}

Mass-specific nutrient excretion rates were significantly different between the two fish species. Nitrogen MSER for seabream $\left(22.8 \pm 3.51 \mu \mathrm{gN} \cdot \mathrm{g}^{-1} \cdot \mathrm{h}^{-1}\right.$, mean $\left.\pm \mathrm{SD}\right)$ was much higher than for mullet $\left(3.51 \pm 2.99 \mu \mathrm{gN} \cdot \mathrm{g}^{-1} \cdot \mathrm{h}^{-1}\right)(p$-value $=0.004)$, while phosphorous MSER for seabream $\left(2.1 \pm 0.38 \mu \mathrm{gP} . \mathrm{g}^{-1} \cdot \mathrm{h}^{-1}\right)$ was lower than for mullet $\left(2.9 \pm 0.24 \mu \mathrm{gP} . \mathrm{g}^{-1} \cdot \mathrm{h}^{-1}\right)(p$-value $=$ 0.027). As a consequence, the molar $\mathrm{N}: \mathrm{P}$ ratio of the excretion products from seabream (26.0 \pm 1.36$)$ was much higher than from mullet $(3.0 \pm 2.44)$.

\section{Microbial plankton abundance and community structure}

The phytoplankton abundance in the control and mullet tanks fell to less than half during the experiment while it increased more than four times in the tanks with seabream (Fig. 1a) being significantly higher than in the other tanks $(p$-value $=0.005)$.

The phytoplankton community structure was significantly different between treatments $(p$ value $<0.001$; Fig. 4a). Tanks with seabream were dominated by Bacillariophyceae (mainly Cerataulina pelagica and Chaetoceros tenuissimus which between them represented more 
than $80 \%$ of total cells) while tanks with mullet were dominated by Prasinophyceae (>70\% of cells) and Dinophyceae (>20\% of cells) (Figs. 1b-d).

The bacterioplankton abundance decreased during the experiment in all treatments. However, the abundance decreased less in tanks with seabream where the bacterioplankton abundance was twice that in the control and mullet tanks at the end of the experiment (Fig. 2a) ( $p$-value = 0.032). The number of bacterioplankton OTUs was not significantly different between the three treatments at the end of the experiment $(48 \pm 3)(p$-value $>0.05)$. However, the bacterioplankton community structure was significantly different between treatments ( $p$-value $<0.001$; Fig. 4b), as shown by the different OTUs that dominated the bacterioplankton communities in the various treatments (Figs. 2b-c).

The microzooplankton abundance increased during the experiment in all three treatments (Fig. 3a). At the end of the experiment, the abundance in the tanks with seabream was twice that in the control and mullet tanks ( $p$-value $=0.032)$. Flagellates were more abundant but the ratio of ciliates to flagellates was not significantly different between treatments (Fig. 3b).

\section{Discussion}

As expected, the juveniles of the two fish species considered in this experiment had different nutrient excretion rates, with seabream excreting 6.5 times more $\mathrm{N}$ than mullet and 1.3 times less $\mathrm{P}$. These differences in nutrient excretion rates measured on captive fish that had fasted for $36 \mathrm{~h}$ are similar to the differences measured on fish caught in the wild (Villéger et al. 2012). Differences in nutrient excretion rates between species could result from differences in metabolic rates, growth rates and body nutrient content (Allgeier et al. 2015, Vanni \& McIntyre 2016). Juvenile seabreams have a high growth rate during summer (Isnard et al. 
2015), including the development of a massive skull, which could explain the high $\mathrm{N}$ excretion rate associated with a high metabolic activity as well as low $\mathrm{P}$ excretion rates with $\mathrm{P}$ incorporation into the bones (Vanni et al. 2002). These differences in $\mathrm{N}$ and $\mathrm{P}$ excretion rates yielded an 8-fold difference in N:P molar ratio for the excreted nutrients, with seabream excreting at an N:P ratio 1.6 times higher than the Redfield ratio of 16:1 typically found for phytoplankton biomass in marine ecosystems (Redfield 1934) while mullet excreted at a ratio 5 times lower than the Redfield ratio.

The microbial plankton abundance was significantly different between tanks with or without fish as well as between tanks with seabream and tanks with mullet. Firstly, phytoplankton was an order of magnitude more abundant in tanks with seabream than in the control and mullet tanks (Fig. 1). Such an increase in the abundance of phytoplankton due to nutrient excretion by a fish species is consistent with the three times increase in phytoplankton biovolume observed for a lacustrine fish (Schaus \& Vanni, 2000). The overall increase in phytoplankton abundance in tanks with seabream was mostly driven by the increase in the abundance of diatoms (Bacillariophycae) which dominated with more than $80 \%$ of cells at the end of the experiment whereas diatoms were almost absent in the tanks with mullet (Fig. 1). Chlorophytes (Prasinophycae) and Dinoflagellates (Dinophycae) showed the opposite effect with very low relative abundance in tanks with seabream while representing a major part of the population in the control and mullet tanks. These very different responses of the phytoplankton clades to the presence of fish resulted in significant Bray-Curtis distances between tanks (Fig. 4a). Schaus \& Vanni (2000) found similar differences in the response of phytoplankton clades to nutrient excretion by fish in a lake: there was a marked increase in abundance of all clades other than diatoms. These were probably Si limited in the lake whereas, in the Si-rich Thau Lagoon, phytoplankton is probably N limited (Bec et al. 2005). 
The response of the bacterioplankton to the presence of fish was similar to that of the phytoplankton with the abundance in the tanks with seabream being twice the abundance in the tanks with mullet (Fig. 2a). In addition, the relative abundances of OTUs in tanks with fish were different from those in tanks without fish (Figs. 2b-c). For example, the most abundant OTU in tanks without fish had a relative abundance close to $0 \%$ in tanks with seabream (Fig. 2c, OTU D), while the most abundant OTU in tanks with seabream (15\%) had a relative abundance of less than $5 \%$ of total abundance in the tanks without fish (Fig. 2, OTU B). In addition, the bacterioplankton community structure also depended on the species of fish in the tank. For example, the most abundant OTU in tanks with seabream had a relative abundance less than 5\% in tanks with mullet (Fig. 2, OTU B). The nutrient excretion by each species of fish, therefore, affects the growth of each bacterial OTU differently and, therefore modifies the bacterioplankton community structure (Fig. 4). To our knowledge this is the first time nutrient excretion by fish has been shown to have a positive effect on heterotrophic bacteria as previous studies on the effects of fish excretion have focused on phototrophic unicellular organisms, including cyanobacteria (Schaus \& Vanni, 2000). Further studies are needed to identify the OTUs benefiting most from the presence of fish as well as to test whether they benefit directly from the nutrients released by the fish or indirectly from the metabolites excreted by phytoplankton (Fouilland et al 2014). The consequences for carbon, nitrogen and phosphorus cycling within the microbial compartment and the extension to complete ecosystems will also require further investigation.

The nutrients supplied by the seabream stimulated the growth of both phytoplankton and bacterioplankton (Figs 1,2). As a consequence, the abundance of microzooplankton grazing on phytoplankton and bacterioplankton was four times higher in tanks with seabream than in 
tanks without fish (Fig. 3). Nutrient excretion by seabream can thus induce bottom-up effects through the microbial food web with a significantly higher abundance of both primary and secondary producers. Furthermore, the overall shift in the community structure of the phytoplankton and bacterioplankton, induced by the presence of seabream, was associated with a lower variability of the community structure between tanks with seabream than between tanks without fish (Fig. 4). The nutrients supplied by the fish cause competition for nutrients and, therefore, increase the influence of deterministic assembly rules, while, in the absence of fish, random factors could have a greater influence on the microbial community structure (Hibbing et al. 2010, Stocker 2012).

Mullet did not have a significant positive effect on phytoplankton and bacterioplankton abundance and this may be related to the low $\mathrm{N}: \mathrm{P}$ ratio of the nutrients excreted by this species. Even if some phytoplankton and bacterioplankton species may have been able to grow with this restricted $\mathrm{N}$ supply, this growth was insufficient to counteract the grazing pressure from microzooplankton (i.e. flagellates and ciliates), and so the growth of the microbial community as a whole was limited by $\mathrm{N}$ availability.

\section{Conclusions}

Overall the results from this experiment show that some fish species can increase the abundance of marine phytoplankton when their growth is limited by nutrient availability, as well as increasing the abundance of some bacterioplankton. Furthermore, in Thau Lagoon in summer when there are no external inputs the nutrients released by seabream (ca. $7 \mu \mathrm{gN} \mathrm{L}^{-1} \mathrm{~h}^{-}$ ${ }^{1}$ ) can sustain a large fraction $(30 \%)$ of the primary production estimated from $\mathrm{NH}_{4}$ cycling measurements (Chapelle et al., 2000). This experiment also showed that the increases in abundance of some microbial primary producers due to excretion by fish have bottom-up 
effects on the whole structure of the microbial assemblages and the abundance of microzooplankton. However, the magnitude of these effects is significantly different between fish species and depends on their $\mathrm{N}$ and $\mathrm{P}$ excretion rates. Therefore, the effect of fish on plankton communities is likely to depend on both the limiting nutrient for microbial growth and the nutrient excretion rates of the whole fish assemblage.

Future studies should test the long-term effects of different types of fish assemblages on the whole structure of coastal marine ecosystems, covering all plankton compartments (including zooplankton grazing on large phytoplankton and microzooplankton) as well as benthic primary producers that can compete with microbial plankton for assimilating nutrients released by fish. Recent progress in sequencing technologies (e.g. metabarcoding) makes it possible to assess the abundance of all bacteria OTUs and phytoplankton species simultaneously, especially rare taxa, as well as assessing the expression of their nutrient assimilation genes. This will help to understand the details of the response of plankton to nutrient release by fish. Furthermore, it will be necessary to study the top-down regulation of the abundance of other organisms through predation by fish at the same time as studying the bottom-up effects of nutrients released by fish (Hobbie \& Villéger 2015). 


\section{Acknowledgments}

We would like to thank Arthur Escalas, Thibault Geoffroy, Eva Maire, Cyrille Przybyla and

Fabien Rieuvilleneuve for their help during the experiment. Part of the work presented in this article was carried out at the MICROBEX experimental facility, Montpellier, and at the MARBEC analytical facility, Sète. 


\section{References}

Allgeier JE, Burkepile DE, Layman CA (2017) Animal pee in the sea: consumer-mediated nutrient dynamics in the world's changing oceans. Glob Chang Biol:1-13

Allgeier JE, Wenger SJ, Rosemond AD, Schindler DE, Layman C a (2015) Metabolic theory and taxonomic identity predict nutrient recycling in a diverse food web. Proc Natl Acad Sci 112:E2640-E2647

Anderson MJ (2001) A new method for non parametric multivariate analysis of variance. Austral Ecol 26:32-46

Anderson MJ (2006) Distance-based tests for homogeneity of multivariate dispersions. Biometrics 62:245-253

Appeltans, W., P. Bouchet, G. A. Boxshall, C. DeBroyer, N. J. DeVoogd, D. P. Gordon, B. W. Hoeksema, T. Horton, M. Kennedy, J. Mees, G. C. B. Poore, G. Read, S. Stöhr, T. C. Walter, and M. J. C. (eds) 2013. World Register of Marine Species. Available from http://www.marinespecies.org at VLIZ. (accessed 2013-06-15).

Azam F, Malfatti F (2007) Microbial structuring of marine ecosystems. Nat Rev Microbiol $5: 782-791$

Bec B, Husseini-Ratrema J, Collos Y, Souchu P, Vaquer A (2005) Phytoplankton seasonal dynamics in a Mediterranean coastal lagoon: Emphasis on the picoeukaryote community. J Plankton Res 27:881-894

Benitez-Nelson CR (2000) The biogeochemical cycling of phosphorus in marine systems. Earth-Science Rev 51:109-135

Benjamini Y, Hochberg Y (1995) Controlling the false discovery rate: a practical and powerful approach to multiple testing. J R Stat Soc B 57:289-300

Boulêtreau S, Cucherousset J, Villéger S, Masson R, Santoul F (2011) Colossal aggregations 
of giant alien freshwater fish as a potential biogeochemical hotspot. PLoS One 6:e25732 Burkepile DE, Allgeier JE, Shantz AA, Pritchard CE, Lemoine NP, Bhatti LH, Layman CA (2013) Nutrient supply from fishes facilitates macroalgae and suppresses corals in a Caribbean coral reef ecosystem. Sci Rep 3:1493

Capps KA, Flecker AS (2013) Invasive fishes generate biogeochemical hotspots in a nutrientlimited system. PLoS One 8:e54093

Chapelle A, Ménesguen A, Deslous-Paoli J-M, Souchu P, Mazouni N, Vaquer A, Millet B (2000) Modelling nitrogen, primary production and oxygen in a Mediterranean lagoon. Impact of oysters farming and inputs from the watershed. Ecol Modell 127:161-181

Christensen V, Coll M, Buszowski J, Cheung WWL, Frölicher T, Steenbeek J, Stock CA, Watson RA, Walters CJ (2015) The global ocean is an ecosystem: simulating marine life and fisheries. Glob Ecol Biogeogr 24:507-517

Danger M, Oumarou C, Benest D, Lacroix G (2007) Bacteria can control stoichiometry and nutrient limitation of phytoplankton. Funct Ecol 21:202-210

Danger, M., Daufresne, T., Lucas, F., Pissard, S. \& Lacroix, G. (2008) Does Liebig's law of the minimum scale up from species to communities? Oikos, 117, 1741-1751.

Donald DB, Bogard MJ, Finlay K, Bunting L, Leavitt PR (2013) Phytoplankton-Specific Response to Enrichment of Phosphorus-Rich Surface Waters with Ammonium, Nitrate, and Urea . PLoS One 8:e53277

Elser JJ, Urabe J. (1999) The stoichiometry of consumer-driven nutrient recycling: theory, observations, and consequences. Ecology, 80: 735-751

Elser JJ, Bracken MES, Cleland EE, Gruner DS, Harpole WS, Hillebrand H, Ngai JT, Seabloom EW, Shurin JB, Smith JE (2007) Global analysis of nitrogen and phosphorus limitation of primary producers in freshwater, marine and terrestrial ecosystems. Ecol Lett 10:1135-1142 
Fouilland E, Tolosa T, Bonnet D, Bouvier C, Bouvier T, Bouvy M, Got P, Le Floc'h E, Mostajir B, Roques C, Sempéré R, Sime-Ngando T, Vidussi F (2014) Bacterial carbon dependence on freshly produced phytoplankton exudates under different nutrient availability and grazing pressure conditions in coastal marine waters. FEMS Microbiology Ecology 87: 757-769

Frederiksen M, Edwards M, Richardson AJ, Halliday NC, Wanless S (2006) From plankton to top predators: bottom-up control of a marine food web across four trophic levels. J Anim Ecol 75:1259-68

Froese R, Pauly D. (2018) FishBase. http://www.fishbase.org.

Frost PC, Evans-white MA, Finkel Z V, Jensen TC, Matzek V (2005) Are you what you eat? Physiological constraints on organismal stoichiometry in an elementally world imbalanced. Oikos 109:18-28

Hibbing ME, Fuqua C, Parsek MR, Peterson SB (2010) Bacterial competition: surviving and thriving in the microbial jungle. Nat Rev Microbiol 8:15-25

Hobbie SEH, Villéger S (2015) Interactive effects of plants, decomposers, herbivores, and predators on nutrient cycling. In: Hanley TC, Pierre KJ La (eds) Trophic Ecology: Bottom-up and top-down interactions across aquatic and terrestrail systems. Cambridge University Press, Cambridge, p 233-259

Hoppenrath M, Elbrächter M, Drebes G (2009) Marine Phytoplankton. Selected microphytoplankton species from the North Sea around Helgoland and Sylt. Schweizerbart Sche Vlgsb

Ip YK, Chew SF (2010) Ammonia production, excretion, toxicity, and defense in fish: a review. Front Physiol 1:134

Isnard E, Tournois J, McKenzie DJ, Ferraton F, Bodin N, Aliaume C, Darnaude AM (2015) Getting a Good Start in Life? A Comparative Analysis of the Quality of Lagoons as 
Juvenile Habitats for the Gilthead Seabream Sparus aurata in the Gulf of Lions. Estuaries and Coasts 38: 1937-1950

Kirchman DL (2008) Microbial ecology of the oceans. 2nd ed. Kirchman,D.L. (ed) John Wiley \& Sons, Inc., Hoboken, New Jersey, 593 p

Kraberg A, Baumann M, Dürselen CD (2010) Coastal phytoplankton. Photo guide for Northern European Seas. Verlag, Munchen, Germany

Layman CA, Allgeier JE, Rosemond AD, Dahlgren CP, Yeager LA (2011) Marine fisheries declines viewed upside down: human impacts on consumer-driven nutrient recycling. Ecol Appl 21:343-349

Legendre L, Rassoulzadegan R (1995) Plankton and nutrient dynamics in marine waters. Ophelia 41: 153-172.

Litchman E, Klausmeier CA, Bossard P (2004) Phytoplankton nutrient competition under dynamic light regimes. Limnol Oceanogr 49:1457-1462

Marañón E, Cermeño P, López-Sandoval DC, Rodríguez-Ramos T, Sobrino C, Huete-Ortega M, Blanco JM, Rodríguez J (2013) Unimodal size scaling of phytoplankton growth and the size dependence of nutrient uptake and use. Ecol Lett 16:371-379

Marie D, Partensky F, Vaulot D, Brussaard C (1999) Enumeration of Phytoplankton, Bacteria, and Viruses in Marine Samples. Curr Protoc Cytom 10:11.11.1-11.11.15

McIntyre PB, Flecker AS, Vanni MJ, Hood JM, Taylor BW, Thomas SA (2008) Fish distributions and nutrient cycling in streams: can fish create biogeochemical hotspots. Ecology 89:2335-2346

Meyer JL, Schultz ET (1985) Migrating Haemulid Fishes as a Source of Nutrients and Organic Matter on Coral Reefs. Limnol Oceanogr 30:146-156 
Mouchet M, Bouvier C, Bouvier T, Troussellier M, Escalas A, Mouillot D (2012) Genetic difference but functional similarity among fish gut bacterial communities through molecular and biochemical fingerprints. FEMS Microbiol Ecol 79:568-580.

Muyzer G, De Waal EC, Uitterlinden AG (1993) Profiling of complex microbial populations by denaturing gradient gel electrophoresis analysis of polymerase chain reaction amplified genes coding for 16S rRNA. Appl Environ Microbiol 59:695-700

NF EN 15204 (2006) Norme guide pour le dénombrement du phytoplankton par microscopie inverse (méthode Utermöhl) (Technique CEN/TC 230 “Analyse de L’eau,” Ed.).

\section{AFNOR}

Øvreås L, Forney L, Daae FL, Torsvik V (1997) Distribution of bacterioplankton in meromictic lake Saelenvannet, as determined by denaturing gradient gel electrophoresis of PCR-amplified gene fragments coding for 16S rRNA. Appl Environ Microbiol

Redfield, A. (1934). On the proportions of organic derivatives in sea water and their relation to the composition of plankton. James Johnstone Memorial Volume, University Press of Liverpool: $177-192$

Roman J, McCarthy JJ (2010) The whale pump: marine mammals enhance primary productivity in a coastal basin. PLoS One 5:e13255

Schaus MH, Vanni MJ (2000) Effects of gizzard shad on phytoplankton and nutrient dynamics: role of sediment feeding and fish size. Ecology 81:1701-1719

Shantz AA, Ladd MC, Schrack E, Burkepile DE (2015) Fish-derived nutrient hotspots shape coral reef benthic communities. Ecol Appl 25:2142-2152

Stocker R (2012) Marine microbes see a sea of gradients. Science 338:628-633

Tilman D, Kiesling R, Sterner R, Kilham SS, Johnson F (1986) Green, bluegreen and diatom algae: Taxonomic differences in competitive ability for phosphorus, silicon and nitrogen. Arch fur Hydrobiol 106:473-485 
Tomas C, Halse G, Syvertsen E, Steidinger K, Tangen K, Throndsen J, Heimdal B (1997) Identifying marine phytoplankton. Academic Press

Torres LE, Vanni, MJ (2007) Stoichiometry of nutrient excretion by fish: interspecific variation in a hypereutrophic lake. Oikos, 116:259-270

Utermöhl H (1958) Zur Vervollkommnung der quantitativen Phytoplankton-Method. Int ver theor angew limnol 9:1-39

Vanni MJ (2002) Nutrient cycling by animals in freshwater ecosystems. Annu Rev Ecol Syst $33: 341-370$

Vanni MJ, Flecker AS, Hood JM, Headworth JL (2002) Stoichiometry of nutrient recycling by vertebrates in a tropical stream: linking species identity and ecosystem processes. Ecol Lett 5:285-293

Vanni MJ, McIntyre PB (2016) Predicting nutrient excretion of aquatic anaimals with metabolic theory of ecology and ecological stoichiometry: A global synthesis. Ecology 97: $3460-3471$

Vilicic D (2014) Ecology and composition of phytoplankton in the Adriatic Sea. Koeltz Scientific Books

Villéger S, Ferraton F, Mouillot D, Wit R de (2012) Nutrient recycling by coastal macrofauna: intra- versus interspecific differences. Mar Ecol Prog Ser 452:297-303

Voss M, Bange HW, Dippner JW, Middelburg JJ, Montoya JP, B PTRS, Ward B (2013) The marine nitrogen cycle : recent discoveries, uncertainties and the potential relevance of climate change. Philos Trans R Soc Lond B Biol Sci 368:20130121

Whiles MR, Huryn AD, Taylor BW, Reeve JD (2009) Influence of handling stress and fasting on estimates of ammonium excretion by tadpoles and fish : recommendations for designing excretion experiments. Limnol Oceanogr Methods 7:1-7 


\section{Figures}
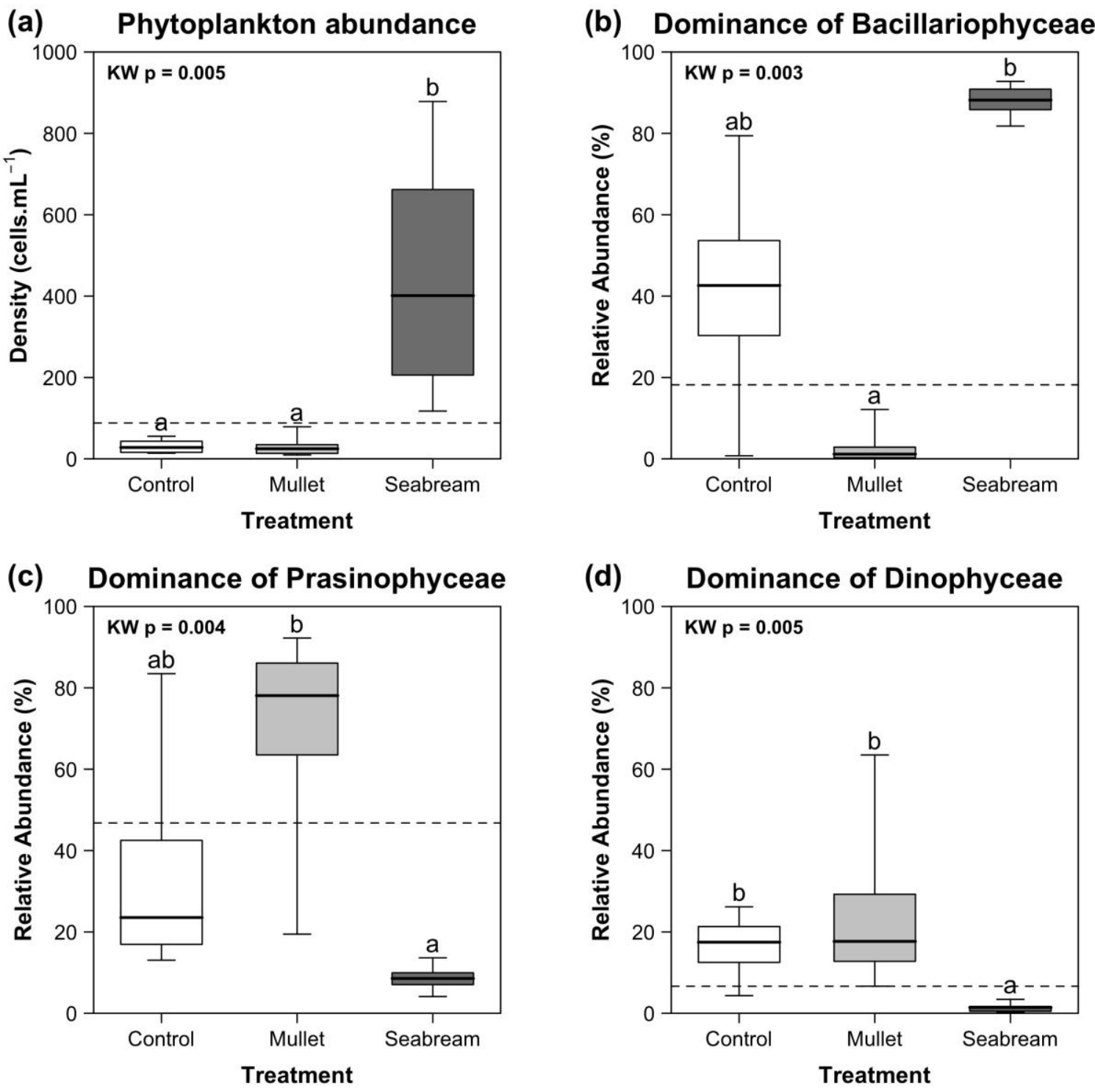

Fig 1. Effect of fish on phytoplankton abundance and community structure.

(a) Total abundance of phytoplankton at the end of the experiment and (b-d) Relative abundance of the 3 most abundant phytoplankton taxonomic groups. Boxes represent $1^{\text {st }}$ to $3^{\text {rd }}$ quartiles, horizontal lines show the medians and whiskers show the range of values for all tanks for each treatment $($ Control $=$ no fish, Seabream $=$ juveniles of Sparus aurata, Mullet $=$ juveniles of Chelon auratus). Horizontal dashed lines show the average values at the start of the experiment. $K W p$ at the top-left corner is the Kruskal-Wallis $p$-value. Different letters show treatments that are significantly different (Dunn post-hoc test $p<0.05$ ). 


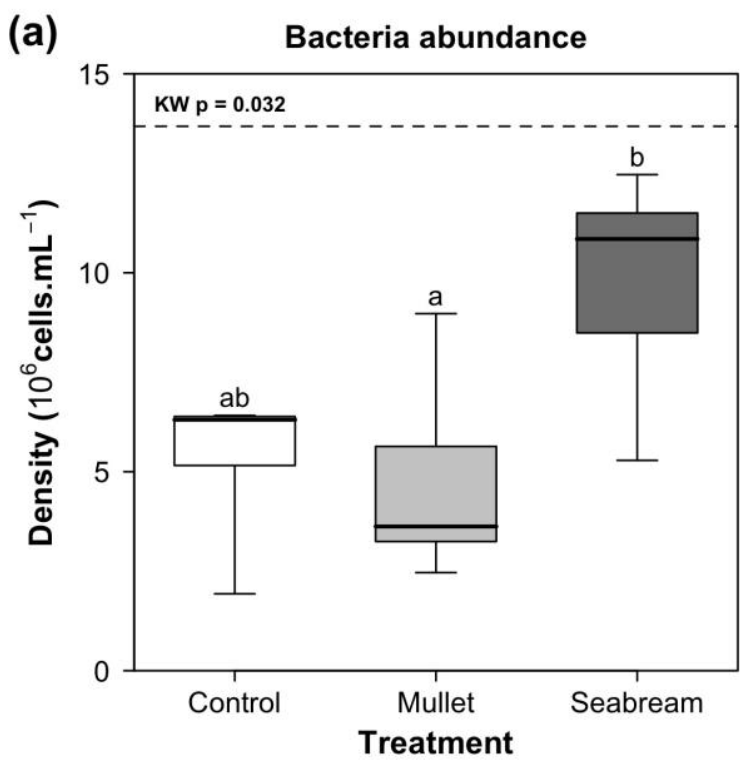

(b)

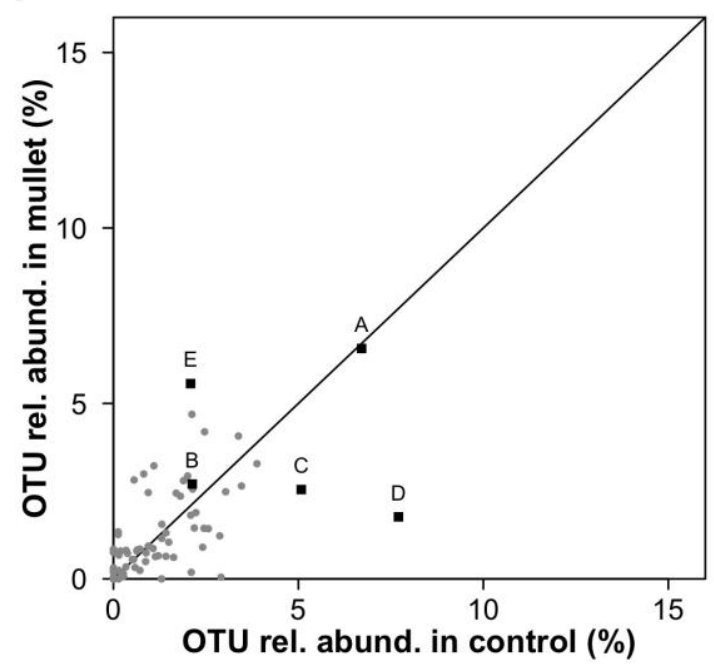

(c)

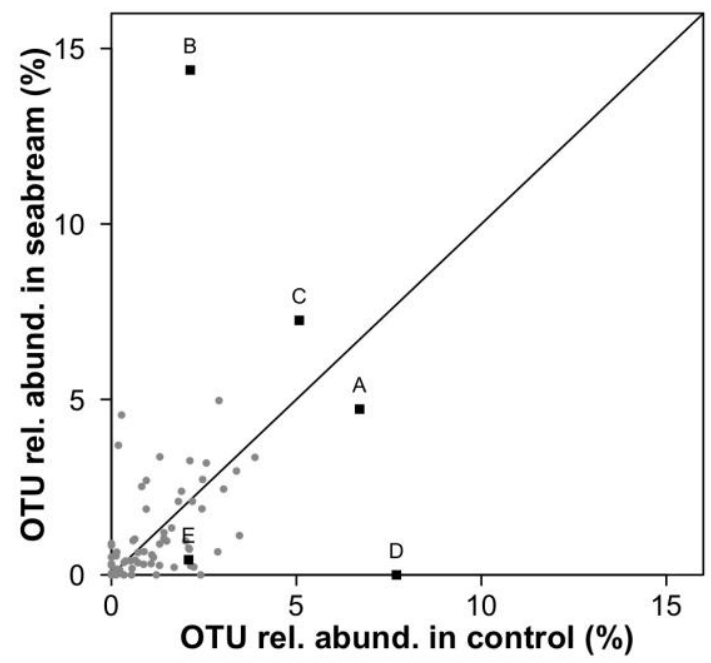

Fig 2. Effect of fish on bacterioplankton abundance and community structure. 
(a) Total abundance of bacterioplankton at the end of the experiment. Boxes represent $1^{\text {st }}$ to $3^{\text {rd }}$ quartiles, horizontal lines show the medians and whiskers show the range of values for all tanks for each treatment $($ Control $=$ no fish, Seabream $=$ juveniles of Sparus aurata, Mullet $=$ juveniles of Chelon auratus). The horizontal dashed line shows the average value at the start of the experiment. $K W p$ at the top-left corner is the Kruskal-Wallis $p$-value. Different letters show treatments that are significantly different (Dunn post-hoc test $p<0.05$ ).

(b-c) Average relative abundance of bacterial OTUs in the control and in the two fish treatments. Points represent values averaged across the replicates. Black labeled squares represent the five OTUs that had an average relative abundance higher than 5\% in at least one of the three treatments. 

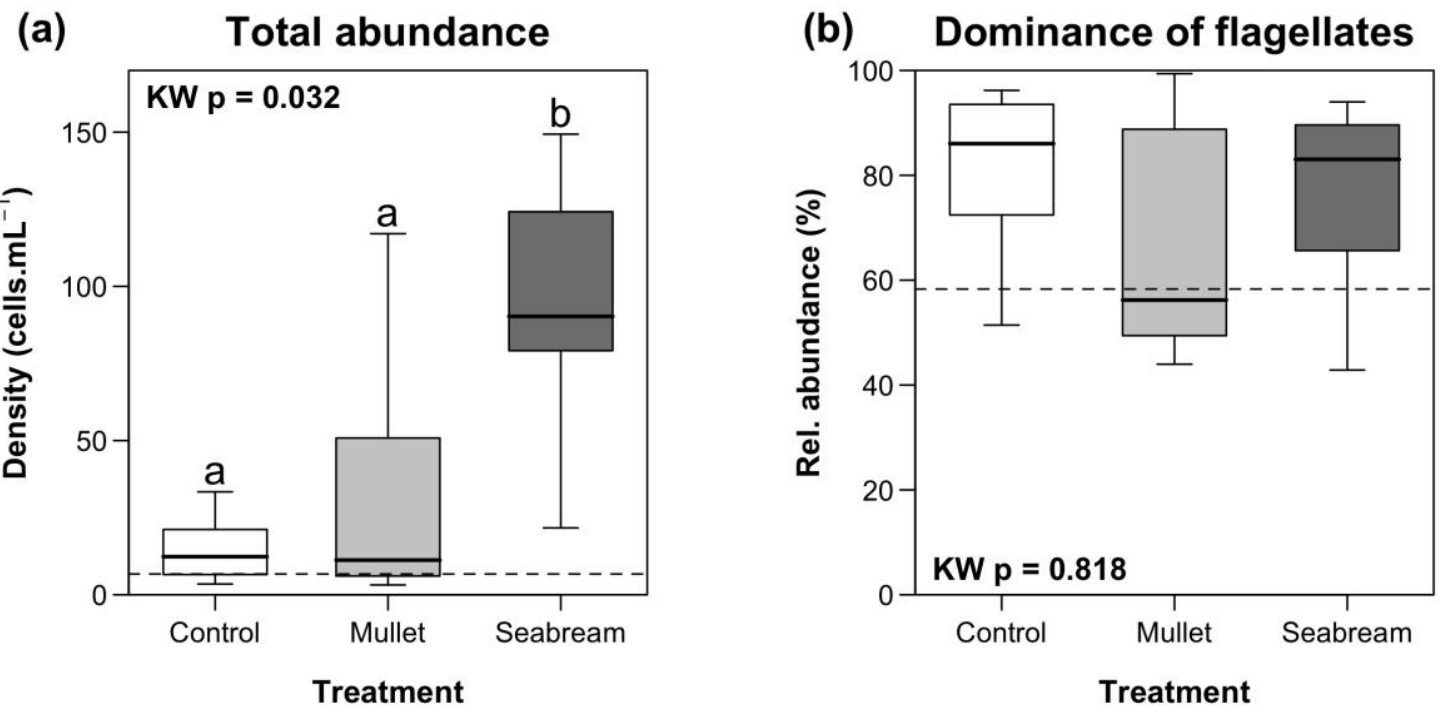

\section{Fig 3. Effect of fish on microzooplankton abundance}

(a) Total abundance of microzooplankton grazing on bacteria and phytoplankton (i.e. ciliates and flagellates) at the end of the experiment and (b) Relative abundance of flagellates. Boxes represent $1^{\text {st }}$ to $3^{\text {rd }}$ quartiles, horizontal lines show the median and whiskers show the range of values for all tanks for each treatment $(\mathrm{Control}=$ no fish, Seabream $=$ juveniles of Sparus aurata, Mullet $=$ juveniles of Chelon auratus). Horizontal dashed lines show the average value at the start of the experiment. $K W p$ at the top-left corner is the Kruskal-Wallis $p$-value. Different letters show treatments that are significantly different (Dunn post-hoc test $p<0.05$ ). 


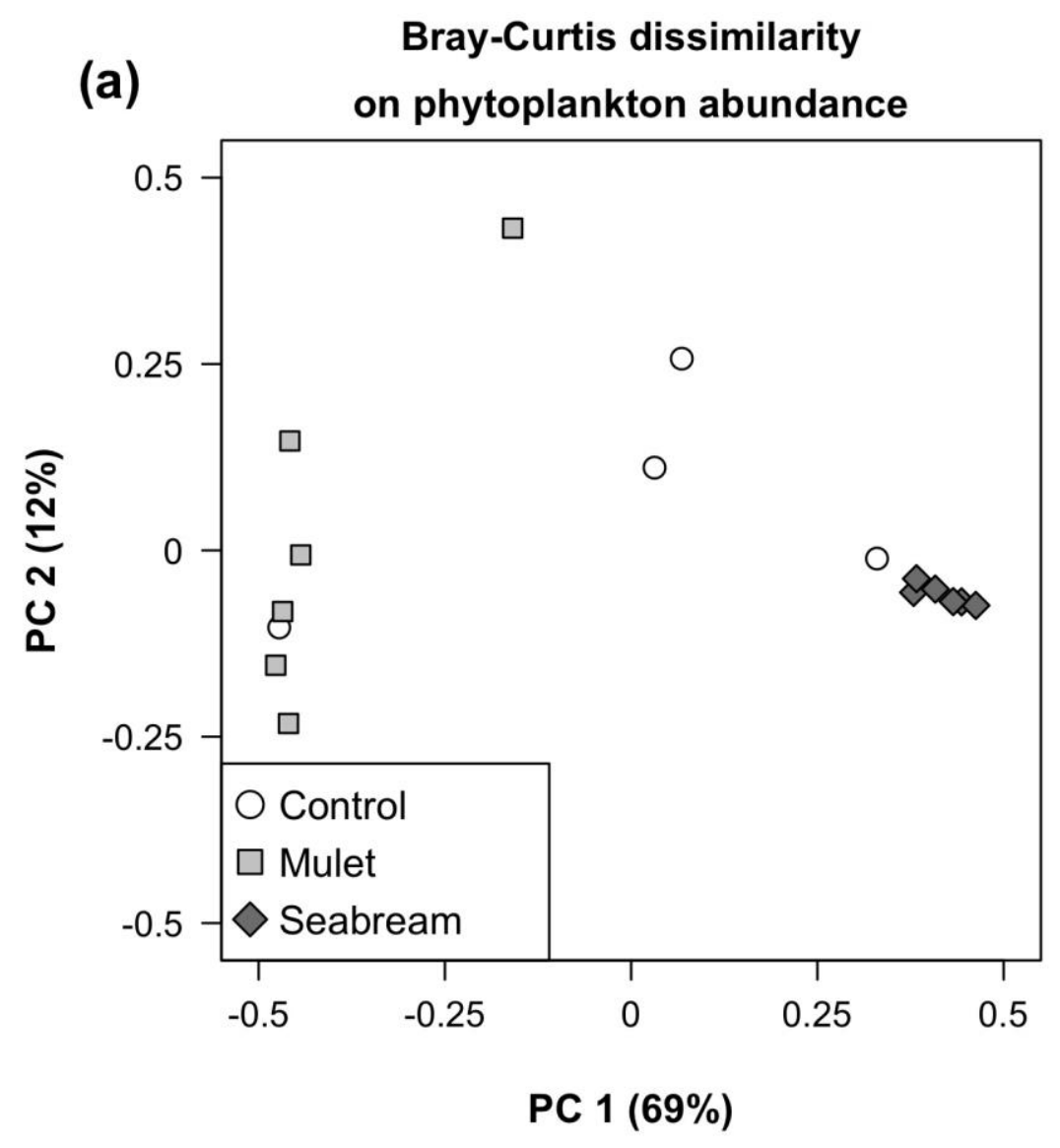

(b)

Bray-Curtis dissimilarity

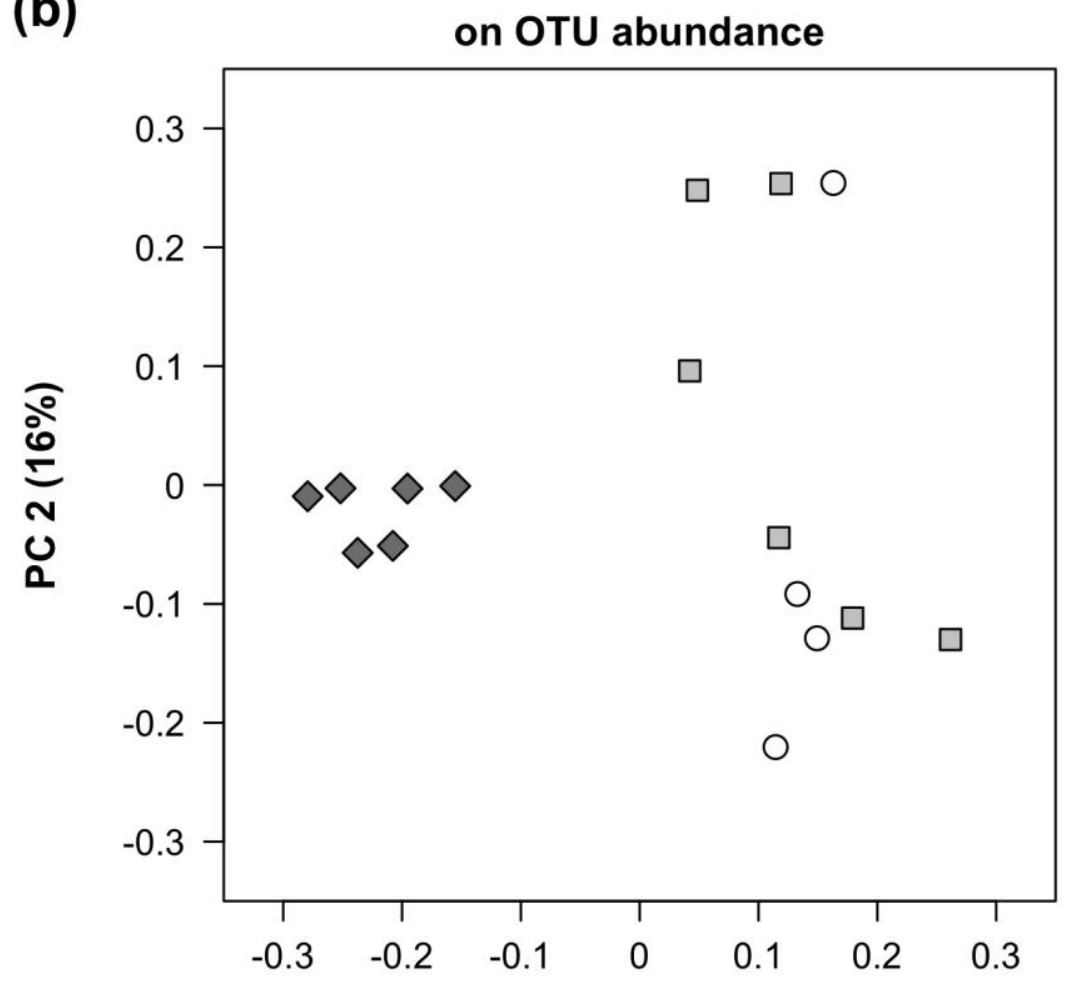

PC 1 (26\%) 
Fig 4. Effect of fish on phytoplankton and bacterioplankton community structures

Principal coordinates analysis of the Bray-Curtis distance calculated a) using the abundances of phytoplankton taxonomic groups and b) using the abundances of bacterial OTUs in each treatment $($ Control $=$ no fish, Seabream $=$ juveniles of Sparus aurata, Mullet $=$ juveniles of Chelon auratus) at the end of the experiment. 